\title{
跑 New Disease Reports \\ Necrotic streak disease of tomato in Florida caused by a new ilarvirus species related to Tulare apple mosaic virus
}

\author{
S. Adkins ${ }^{1}$, C.A. Baker ${ }^{2}$, I.E. Badillo-Vargas ${ }^{3}$, G. Frantz ${ }^{4}$, H.C. Mellinger ${ }^{4}$, N. Roe $^{5}$ and J.E. Funderburk ${ }^{3}$ \\ ${ }^{1}$ USDA-ARS, Fort Pierce, Florida, United States $34945 ;{ }^{2}$ FDACS-DPI, Gainesville, Florida, United States $32608 ;{ }^{3}$ University \\ of Florida, NFREC, Quincy, Florida, United States 32351; ${ }^{4}$ Glades Crop Care, Inc., Jupiter, Florida, United States 33458; ${ }^{5}$ \\ Farming Systems Research, Inc., Boynton Beach, Florida, United States 33474 \\ *E-mail: scott.adkins@ars.usda.gov
}

Received: 17 Mar 2015. Published: 11 Apr 2015. Keywords: Tomato necrotic streak virus, necrosis, movement protein, coat protein

During surveys for the emerging tospoviruses Tomato chlorotic spot virus (TCSV) and Groundnut ringspot virus (GRSV), virus-like necrosis of leaves, petioles and stems (Fig. 1), and necrotic rings or spots on fruits (Fig. 2) of fresh market tomato plants were observed in south (Miami-Dade County) and southeast (Palm Beach County) Florida beginning in October 2013. Incidence of plants with symptoms was generally less than $3 \%$ but in some fields was considerably higher. More than 1000 plants were rogued on a single farm in Miami-Dade County during the fall 2013 season. Total RNA was extracted from representative samples using a RNeasy Plant Mini Kit (Qiagen, Valencia, CA) and tested for TCSV, GRSV and Tomato spotted wilt virus by RT-PCR as previously described (Webster et al., 2015). When no products were amplified, nine virus/viroid genera or groups, and an additional ten virus species including the ilarviruses Tobacco streak virus (TSV) and Tomato necrotic spot virus (ToNSV; Batuman et al., 2009) were assayed by RT-PCR and/or DAS-ELISA (Agdia, Inc., Elkhart, IN) all with negative results. Light microscopic examination for inclusion bodies revealed no known virus-induced structures. Symptomatic tomato plant tissue was used to mechanically inoculate tomato plants, and symptoms of leaf, petiole and stem necrosis similar to those observed in the original field samples developed in the inoculated tomato plants.

Ultimately, a 412 bp fragment (GenBank Accession No. KP861233) was amplified from total RNA by RT-PCR using ilarvirus primers provided by Agdia, Inc. Sequence analysis indicated that the nucleotide (nt) and deduced amino acid (aa) sequences of the fragment were 68 to $80 \%$ and 67 to $83 \%$ identical, respectively, to RNA1 and the replicase protein 1a of subgroup 2 ilarviruses with considerably less identity to other previously reported subgroup 1 tomato-infecting ilarviruses including TSV (54\% nt, $43 \%$ aa) and Parietaria mottle virus (49\% nt, $46 \%$ aa; Galipienso et al., 2005). Thus, primers were designed from conserved regions of available RNA3 sequences of subgroup 2 ilarviruses [Asparagus virus 2, Citrus leaf rugose virus, Citrus variegation virus, Elm mottle virus, Spinach latent virus and Tulare apple mosaic virus (TAMV)] and used to amplify the movement protein (MP) and coat protein (CP) genes. Sequence analysis showed that the MP and CP genes (KP861234 and KP861235) were most closely related to, but distinct from, TAMV at 79 and $83 \%$ identity, respectively.
Deduced MP and CP aa sequences were 76 and $77 \%$ identical, respectively, to those of TAMV. These results indicate that the tomato symptoms initially observed in Florida in fall 2013, and subsequently in spring and fall 2014, are caused by a new subgroup 2 ilarvirus species, for which the name Tomato necrotic streak virus (TomNSV) is proposed. Potential TomNSV transmission by pollen, seed and/or insect vectors that may include thrips similar to other ilarviruses (Sdoodee \& Teakle, 1987; Aramburu et al., 2010) is not currently known and requires additional research.

\section{Acknowledgements}

The authors would like to thank Carrie Vanderspool, Jason Skaryd, Shelby Hanson and Rita Noel for their excellent technical assistance.

\section{References}

Aramburu J, Galipienso L, Aparicio F, Soler S, López C, 2010. Mode of transmission of Parietaria mottle virus. Journal of Plant Pathology 92, 679-684.

Batuman O, Miyao G, Kuo YW, Chen LF, Davis RM, Gilbertson RL, 2009. An outbreak of a necrosis disease of tomato in California in 2008 was caused by a new ilarvirus species related to Parietaria mottle virus. Plant Disease 93, 546. http://dx.doi.org/10.1094/PDIS-93-5-0546C

Galipienso L, Herranz MC, Pallás V, Aramburu J, 2005. Detection of a tomato strain of Parietaria mottle virus $(\mathrm{PMoV})$ by molecular hybridization and RT-PCR in field samples from north-eastern Spain. Plant Pathology 54, 29-35. http://dx.doi.org/10.1111/j.1365-3059.2005.01109.x

Sdoodee R, Teakle DS, 1987. Transmission of Tobacco streak virus by Thrips tabaci: a new method of plant virus transmission. Plant Pathology 36, 377-380. http://dx.doi.org/10.1111/j.1365-3059.1987.tb02247.x

Webster CG, Frantz G, Reitz SR, Funderburk, JE, Mellinger HC, McAvoy E, Turechek WW, Marshall SH, Tantiwanich Y, McGrath MT, Daughtrey ML, Adkins S, 2015. Emergence of Groundnut ringspot virus and Tomato chlorotic spot virus in vegetables in Florida and the southeastern United States. Phytopathology 105, 388-398. http://dx.doi.org/10.1094/PHYTO-06-14-0172-R

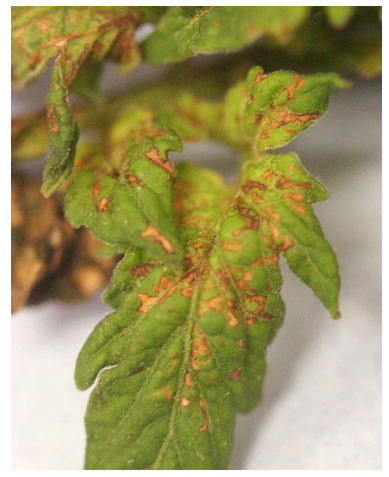

Figure 1
Figure 2

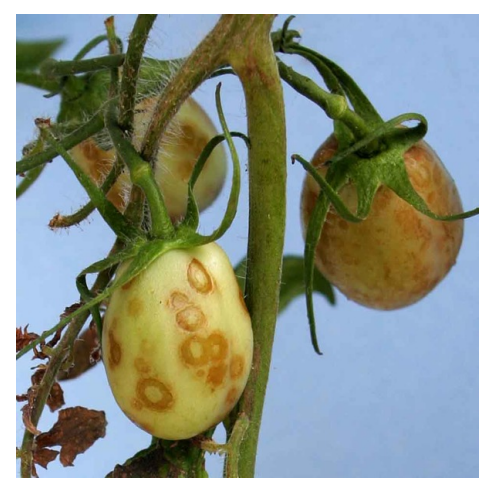

To cite this report: Adkins S, Baker CA, Badillo-Vargas IE, Frantz G, Mellinger HC, Roe N, Funderburk JE, 2015. Necrotic streak disease of tomato in Florida caused by a new ilarvirus species related to Tulare apple mosaic virus. New Disease Reports $\mathbf{3 1}, 16$. http://dx.doi.org/10.5197/j.2044-0588.2015.031.016 (C) 2015 The Authors This report was published on-line at www.ndrs.org.uk where high quality versions of the figures can be found. 